\title{
Community Initiated Adaptive Reuse for Culture and the Arts: 'The Tanks Arts Centre' Cairns, Australia
}

\author{
Anthony Castles
}

iD https://orcid.org/0000-0001-6629-9752

James Cook University, Australia

\begin{abstract}
A group of World War II naval fuel storage tanks strategically located in a tropical rainforest in Cairns, Australia, were adapted for arts and cultural purposes. This paper explores the adaptive reuse of this unusual industrial heritage site. It uses a case study approach to demonstrate how the social and aesthetic values of the place have been conserved and grown, and how these values have interacted to increase community attachment through a community-initiated approach to the site's reuse. A scoping review and secondary data helped develop the case study and informed semistructured interview questions for key industry stakeholders. The paper deduces that a community-led bottom-up approach to the reuse of space for arts and culture results in greater community attachment and, as opposed to top-down approaches, allows for continued growth in social and aesthetic value. Nevertheless, ongoing success of community initiatives in most cases is also reliant on the structure of a government-led administration.
\end{abstract}

Keywords: Arts and Culture, Adaptive Reuse, Social Value, Aesthetic Value, Community initiated, Industrial Heritage, Urban Tropics, Cairns

eTropic: electronic journal of studies in the tropics publishes new research from arts, humanities, social sciences and allied fields on the variety and interrelatedness of nature, culture, and society in the tropics. Published by James Cook University, a leading research institution on critical issues facing the worlds' Tropics. Free open access, Scopus Listed, Scimago Q2. Indexed in: Google Scholar, DOAJ, Crossref, Ulrich's, SHERPA/RoMEO, Pandora. ISSN 1448-2940. Creative Commons CC BY 4.0 free to download, save and reproduce. To cite, include: Author(s), Title, eTropic, volume, issue, year, pages and DOI: http://dx.doi.org/10.25120/etropic.19.2.2020.3740 
eTropic 19.2 (2020) Special Issue: Sustainable Tropical Urbanism

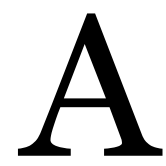

daptive reuse of industrial heritage sites as arts and cultural facilities can often be the best option for an industrial place that can no longer function under its original use. This change in use not only conserves exiting heritage values but can be the catalyst to increase and add new layers of social and aesthetic value. Heritage value grows out of curiosity about and history of the past (Cossins, 2016); it develops an intrinsic value as a landmark or memory within a community. Likewise, industrial heritage can be an historic link to the past; a demonstration of how a place has progressed and become a part of a community's identity (Ireland, 2002). Yet, industrial heritage can also be challenging regarding its aesthetics, scale, past social consequences, and negative perceptions. This paper explores how social and aesthetic values interact in an arts and cultural context to create community attachment to a World War II industrial heritage building. The Tanks Arts Centre, in Cairns, tropical north Australia, forms a compelling case study. It showcases a successful example of a long abandoned industrial site adapted to an attractive and unusual arts centre without compromising its value as a World War II industrial relic and demonstrates how this developed through local drive and passion. The paper plots how a series of community-initiated approaches created a snowballing effect of community attachment and led to an evolving aesthetics of this industrial ruin with its cathedral like proportions set within a tropical rainforest. It shows how historic values have been conserved and aesthetic and social values built through the site's community-initiated reuse. As a result, The Tanks Arts Centre has become one of the most dynamic arts and cultural spaces in regional Australia.

The unique and analytically informative story of the Tanks Arts Centre has not previously been published in the academic literature. This paper is written from an insider's perspective as the author is an employee of The Tanks Arts Centre. Impetus to undertake this research was initiated through witnessing firsthand how the community and successive performing artists continue to appreciate and maintain strong affective attachment to the space.

\section{Literature}

This paper draws literature from the structured process of a scoping review. The mapped literature was selected from academic databases, reference lists and grey literature. Keywords used in the search terms were (Arts OR Cultural) AND ("Adaptive Reuse") AND (Social OR aesthetic). A protocol was developed to identify relevant papers: they had to contain a combination of the keywords, be in English, be published after 1990, and be in the tropics of Australia or South East Asia. This protocol was later expanded to include all of Australia and China, given the limited number of papers 
found in initial searches. Existing papers in the broader grey literature provide evidence on adaptive reuse regulation and policy that set a groundwork for the study (Australian Government, 2006; The Burra Charter, 2013). Several studies explore the barriers and enablers of adaptive reuse, clearly presenting how this process can conserve and protect heritage and gentrify often derelict areas (Bullen \& Love, 2011a; Conejos et al., 2016; Dyson et al., 2016). However, authors also outline the issues of adaptive reuse, including: difficulty in retrofitting services to comply with current building codes, ongoing maintenance requirements, and suitability of buildings to effectively meet the demands of modern uses (Bullen, 2007; Mehr \& Wilkinson, 2018). Nevertheless, Bullen (2007) posits that any shortfalls in building performance should be balanced against the conservation of social value. A number of authors have recognised the concept of social value and how communities attach meaning to a place through continuous involvement with that place and the social interactions that happen within it (Hashemnezhad et al., 2013; Johnston, 1992; Yung \& Chan, 2015). Literature on aesthetic value usually refers to architectural aesthetics, but when referring to aesthetics as a sense of like or dislike to place based on sensory perceptions, evidence is scarce (Bianchi, 2014; Goldman, 2005; Johnston, 2016). Additionally, the literature establishes that social and aesthetic values are subjective and often difficult to define and use in practice (Bailey, 2009; Landorf, 2011; Throsby, 2007).

Academic case studies using the literature protocol were selected that demonstrate adaptive reuse of any type of building for arts and cultural purposes and the subsequent effects on social and aesthetic value (Chang, 2016; Gray et al., 2017). Case studies in China were included for their grassroots initiated approach, subsequently supported by government initiatives, and also the use of industrial buildings (Chen et al., 2018; Yung et al., 2014). Other case studies that discuss adaptive reuse projects for arts and cultural purposes were found in Australian government reports and literature, for example the Queen Victoria Museum and Gallery in the former Launceston railway workshops (Department of Environment and Heritage, 2004); and in the grey literature, the Casula Powerhouse, Carriage Works and The Substation (Eccles, 2008; Spaces, 2016). These comparative China and Australian studies have addressed some interesting questions in the context of exploring the evolving values attached to places, and how through adaptive reuse for arts and cultural purposes new values are created that increase the sense of community attachment. 


\section{Historic Heritage Significance of the Tanks}

The history of The Tanks is bound up in the Pacific arena during World War II. ${ }^{1}$ The Allied Works Council, the constructing body for WWII infrastructure, built five tanks as a fuel storage facility for the Royal Australian Navy in 1943. They were built into the side of the Mt Whitfield Range, in Cairns, to serve the increased shipping needed for the war effort (Department of Heritage and Environment, 2007). The site was chosen on the southern flank of the Range, $4 \mathrm{~km}$ from the port, so the tanks were not obviously associated with the port and could be easily hidden by camouflage nets cast over their roofs in case of air raids. The fuel was pumped through a long underground pipeline to Trinity Inlet where ships docked (Cairns City Council, 2010; Department of Heritage and Environment, 2007).

Tanks 1 and 2 were built first in 1943 at a cost of $£ 2,500$ each. The tanks were constructed on the site of an old railway siding which serviced a neighbouring quarry. They were made of solid steel plate to hold diesel fuel. Tanks 3,4 and 5 were also built in 1943, to contain crude or furnace oil. They were located further west of tanks 1 and 2 on the site of the old quarry. These were constructed using reinforced concrete. The concrete was hand mixed and poured 24 hours a day until finished. Some of the workers have left their names etched into the concrete on top of the perimeter bund wall adjacent to Collins Avenue, a thoroughfare through the botanic gardens precinct that connects Cairns inner suburbs with the city (Cairns City Council, 2010). These labourer's names etched into the bund wall offer wider social value as a record of people's lives, creating an important link to the past and identity of the industrial community of the time (Cossins, 2016).

All five tanks had a continuous role for the storage of fuel throughout the war effort. After the war that use continued; they were rented out to fuel storage and other bulk storage companies as well as being used by the Navy. However, by 1987 , their storage use declined and they had no official function. In 1994 tanks 3, 4 and 5 began their transition into The Tanks Arts Centre.

\footnotetext{
1 Australia's involvement in World War II began in 1939 with almost one million men and women serving as allies with British and other forces. The war came much closer when the Japanese entered in 1941, quickly achieving many victories and threatening Australia's north. Port Moresby, in Papua New Guinea, and Darwin, north Australia, were being bombed in 1942 and it seemed that Australia would be invaded (The Australian War Memorial (2018). This brought Cairns into the near warzone. The arrival of several damaged ships from Darwin brought the reality of the war into Cairns Harbour, compounded by the arrival of other ships fleeing the attack in New Guinea and the South Pacific Islands. The Japanese aimed to isolate Australia so it could not be used as a launch site to fight back, but this tactic failed in the battle of the Coral Sea in May 1942, and American and Australian troops and their war supplies poured into the north to begin the campaign to re-take New Guinea and other Pacific islands. A buildup of military strength was seen in Cairns as a result. Infrastructure in Cairns at this time served a sleepy little tropical town known for sugar, fishing, and tourists, and required much development to turn the town into a military base (Bottoms, 2015)
} 
eTropic 19.2 (2020) Special Issue: Sustainable Tropical Urbanism

\section{Method}

In order to understand this transition from industrial concrete storage tanks to an arts and cultural centre the paper adopts an explanatory case study method as described by Yin in MacCallum et al. (2019). It investigates how social and aesthetic values have been acquired and maintained in places reused for arts and culture. This paper seeks to introduce this concept in the context of The Tanks Arts Centre as unusual reused industrial structures. The Tanks Arts Centre enquiry plays an important role in a larger project in North Queensland that informs further research about social and aesthetic value. This case study undertakes both an historical and contemporary exploration. It investigates why the place was first built, the types of activities that have happened, and who the users were. It explores the site's significance in an historical context by examining how the community may have originally been attached to the place, whether or not it had gone into decline, and how the original use may have changed. The paper subsequently investigates why the place was reused for arts and culture and how the community did (or did not) embrace this new use, and, importantly, how the community were involved in the process. It seeks to illustrate how people have felt about the place then and now.

The Tanks Arts Centre case initially relied on secondary data, drawing upon resources from the Cairns Regional Council archives, heritage registers, and an existing survey. With ethics approval, most of this secondary data was able to be captured as the researcher has been an employee at The Tanks Arts Centre for the past ten years. In 2014 the researcher was tasked to curate a 20-year anniversary exhibition that celebrated The Tanks Arts Centre as a contemporary space. Through this process a diverse range of old photographs, newspaper clippings, and event invitations were uncovered, some stored in filing cabinets, others at the backs of drawers. Archival recordings from an electronic display at The Tanks Arts Centre, now no longer in use, provided interview data with people from the community who had some connection with the place. Additionally, having worked at the centre for a decade has enabled the researcher to undertake a practice of flânerie (Chaudhury \& Lundberg, 2018), casually observing the cultural events and people's interactions with the place.

A second phase of the research project was conducted in 2019, where primary data was collected as semi-structured interviews with twelve key industry stakeholders from the fields of urban planning, architecture, art and culture, as well as with community leaders. The interview questions drew on inductive reasoning from the secondary data that informed an initial case study about 'The Tanks Arts Centre', as well as deductive reasoning from the broader literature review. The interviews were analysed using NVivo, resulting in descriptive statements categorised to keywords. 
eTropic 19.2 (2020) Special Issue: Sustainable Tropical Urbanism

\section{Arts Led Adaptive Reuse}

Adaptive reuse conserves a building and adds a contemporary layer for its new use. Bullen and Love (2011b) and the Department of Environment and Heritage (2004) claim that when adaptive reuse is applied to heritage buildings it not only retains the buildings but also conserves the energy already invested in them. This energy incorporates the materials, effort, skill and dedication of the original builders (Watson, 2016). Furthermore, adaptive reuse can conserve the architectural, social, cultural and historical values of a place, preserving a record of the past and adding character to communities. The grand buildings considered as 'heritage' according to popular taste are usually considered more desirable for reuse rather than those of less obvious value, including industrial spaces. In contrast, Cantell (2005) argues that industrial buildings are significant for their utilitarian architecture: they are vernacular relics from the industrial age, notepads to the past, and enhance the identity of place. As such, they are just as much architectural masterpieces or landmarks as the more obvious grand historic buildings.

A key point is that industrial buildings are especially well-suited to adaptive reuse as arts and cultural facilities due to the large open spaces and intrinsic historic values they offer (Department of Environment and Heritage, 2004). Artists are attracted to them for their cheap rents, as buildings are often located in areas of decline (Chen et al., 2016). However, Westbury (2016), the founder of the Renew Newcastle program in Australia, takes the view that it has become a cliché that artists will gravitate toward and rejuvenate abandoned places, given that in most regional towns and cities cheap rent is a thing of the past. He claims there are no artists waiting to magically reform such sites; rather, he believes the artists are waiting for the sites to be reinvented and revitalised by governments or sympathetic developers. Although this may be true, involving the community offers significant social and cultural benefits over a state-led approach which usually focuses on economic outcomes and can potentially create adverse social conditions (Yung et al., 2014).

The literature demonstrates several examples of how a community-led approach in comparison to state-led directives creates greater community arts and cultural value. Two studies demonstrate the adaptive reuse of heritage buildings by local artists in Beijing, Chongqing and Shanghai, in the 1990s (Chen et al., 2016; O'Connor \& Gu, 2014). The studies outline that artists were attracted by cheap rents, the large open spaces, and their perception of the aesthetic 'feel' of the buildings. As a result of the critical mass of artists creating these arts and cultural spaces, government policy was adopted that supported the promotion of these types of facilities for the benefits they brought in promoting an international image of the arts and in conserving heritage (Chen et al., 2016). Noteworthy in the literature is that not all places are suitable for 
arts and cultural reuse. Arts-led gentrification of shophouses in Singapore found them to be too small for arts related activities, for instance rehearsals or art galleries, and thus their use was reduced to arts office space or storage (Chang, 2016). The state funded initiative in Little India, Singapore, to convert old shophouses and reignite the area through arts-led gentrification resulted in an urban aesthetic giving an impetus for creativity and tourism; however, as Chang (2016) notes, the gentrification process can displace the original inhabitants and serve the agendas of the middle class, as, he argues, has also happened in state-led gentrification in Shanghai. This stands in contrast to community artist-led reuse of factories in China which utilise transitional land abandoned due to a decline in manufacturing and act to spur urban regeneration through an arts-led agenda (Chen et al., 2016). An example from Australia is The Fyansford Paper Mills in Geelong. Seen as an antidote to formal government attempts of artist-led gentrification of declining cities, this study demonstrates the adoption of a grassroots approach that brought the community together who have now become socially invested in the place (Gray et al., 2017).

The Fyansford Paper Mill is an insightful case. Although privately owned, it emphasised the creation of a community asset through volunteer programs and encouraging a maker's culture. It demonstrates grassroots involvement in the conservation of heritage as an art practice itself. It has focused on social outcomes and retaining the original effort, skills and dedication put into the material, design and construction of place (Gray et al., 2017). This community driven approach helped increase the importance of place to the community in understanding the past use of the site, as well as inspiring creativity through an artisan skills adaption process.

\section{The Tanks Arts Centre}

Similar to these international examples, the adaptive reuse of disused Royal Australian Navy (RAN) WWII infrastructure in Cairns to become The Tanks Arts Centre can be attributed to the combined drive from community and creative industries leaders, collaborative community projects, the continued support from Cairns City Council (later Cairns Regional Council), as well as financial support through government funding. In the same fashion as other examples of arts-led adaptive reuse in this paper, The Tanks Arts Centre was not originally reused to conserve its heritage value; rather, it was seen as an opportunity for a much-needed arts and cultural space. The WWII tanks and surrounding land had become transitional land, like that seen in the industrial estates in China (Chen et al., 2016).

The Tanks Arts Centre's recorded WWII and industrial history extends from the war to 1987. There are few records between 1987 and 1991, suggesting the site had no official use during this time, and like many disused industrial buildings was left to fall 
eTropic 19.2 (2020) Special Issue: Sustainable Tropical Urbanism

to ruins. Apart from local historians, few knew of the Tanks' wartime role, and at most the site had landmark significance for the general public - a geographic marker that located them in the local space. Otherwise the tanks existence was arguably a matter of indifference to the community. It is interesting that a community leader, born and bred in Cairns, remembered that the site was a place to avoid as a child: known as a snake haven and experienced as hot concrete tanks amidst overgrown tropical vegetation. In 1991 the Cairns City Council purchased all five of the tanks from the Commonwealth, and the land was transferred to the Council with the intention to use the land as an extension of the Flecker Botanic Gardens recreation reserve, with the tanks to eventually be demolished and the land used for plant nurseries and a carpark. However, former Cairns City Council Community Arts Officer, Carrie Bies, an advocate and hero for the adoption of the project, states that the demolition of the concrete tanks to be used for the arts centre became cost prohibitive as the tanks were so substantially built, with foundations about 6 metres into the ground and thick or heavily reinforced concrete walls (Bies, n.d. b).

Former Councilor Sheppard stated that around 1994 she was on a committee whose purpose was to identify potential spaces for arts and cultural activities in the region, including for the Graft'n'Arts group. Several buildings in Cairns had been identified for use as a permanent base by the newly formed arts committee, and the tanks site was one of these. It was fortunate that Councilor Sheppard was an advocate for the arts and the reuse of the tanks. She brought to a council meeting a report that revealed that $\$ 30,000$ per annum was to be spent on maintaining the unused tanks site against encroaching tropical flora and fauna and impacts of the tropical climate. Clearly it would be much more beneficial to direct these funds toward a much-needed arts and cultural space. Bies stated that the Council became very receptive to the idea of using the facility as a community arts centre as it gave the Council another option of what to do with the disused tanks (Bies, n.d. a).

In its early days The Tanks Arts Centre comprised various arts and culturally based activities under different managers. This changed in 1998 when a formal manager for The Tanks Arts Centre took over. She explains that at that time the people running the place had fallen out with Council and were using it for their own private businesses, such as a printing studio operating in the back sheds using council money for their supplies. As she further states, the Council managers at the time "didn't want to know about it". According to former Councillor Sheppard of the Mulgrave Shire Council (Mulgrave Shire was in the process of amalgamating with Cairns City Council), continued use of the site was discussed during a Cairns City Council meeting c.1998, with Councillors voting to have the precinct fenced, temporarily closed and maintained until a decision on its future was secured. At the same time, the former manager said, the Council didn't know what to do with an arts group called 'Graft'n'Arts'. They were 
eTropic 19.2 (2020) Special Issue: Sustainable Tropical Urbanism

seen as a group that was difficult to manage and were best closed down. Personal communication with a long-term employee of The Tanks Arts Centre backs this up, saying of Graft'n'Arts that although they were Council-run, the staff were left to their own devices to run programs. They were very much community minded and the Council officials enjoyed seeing the creative outcomes, but they were not sure how to manage it. Bies stated that when she was working at Graft'n'Arts at this time, it was the hub of community arts programs in Cairns (Bies, n.d). However, they were in temporary accommodation in a building leased in the Cairns CBD. She said that it was a priority to relocate to permanent premises, as the rental on the CBD property was very expensive for the community group.

The Tanks Arts Centre went on to become a hub of arts and cultural activity. The new manager who commenced in 1998, came up with a program that connected with local artists to exhibit and perform, and a business arm that brought in corporate clients for events such as gala dinners. Graft'n'Arts took up residence at The Tanks Arts Centre along with other arts groups. The former manager said she invited all kinds of people from the community to use the space - with the idea that the more the place was used the sooner the Council would see its worth. It not only became a valued place for emerging local artists to exhibit and perform, but people from Sydney, Melbourne, Brisbane and other locations wanted to exhibit there. As the former manager notes, people loved the place. It was a completely different environment for artists; it was unique.

\section{Aesthetic and Social Values}

Reusing a building as an arts centre would imply that it would have some kind of aesthetic interest. Originally, finding aesthetic appeal in five World War II fuel tanks would have been a challenge. This is not surprising as they were constructed as utilitarian WWII infrastructure with no aesthetics in mind, as seen in Figure 1. However, over time, a positive aesthetic appeal has developed. Their undoubted historic value was recognised in 2007 when they were placed on the Queensland Heritage Register. They were a reminder of how close Cairns was to the war front, and their intactness 62 years after the war finished was unusual. When the Tanks were heritage listed the construction methods used were noted as important in demonstrating design, form, and materials of structures specifically designed for the storage of naval fuel in 1943. 
eTropic 19.2 (2020) Special Issue: Sustainable Tropical Urbanism

Figure 1 Tanks 1943

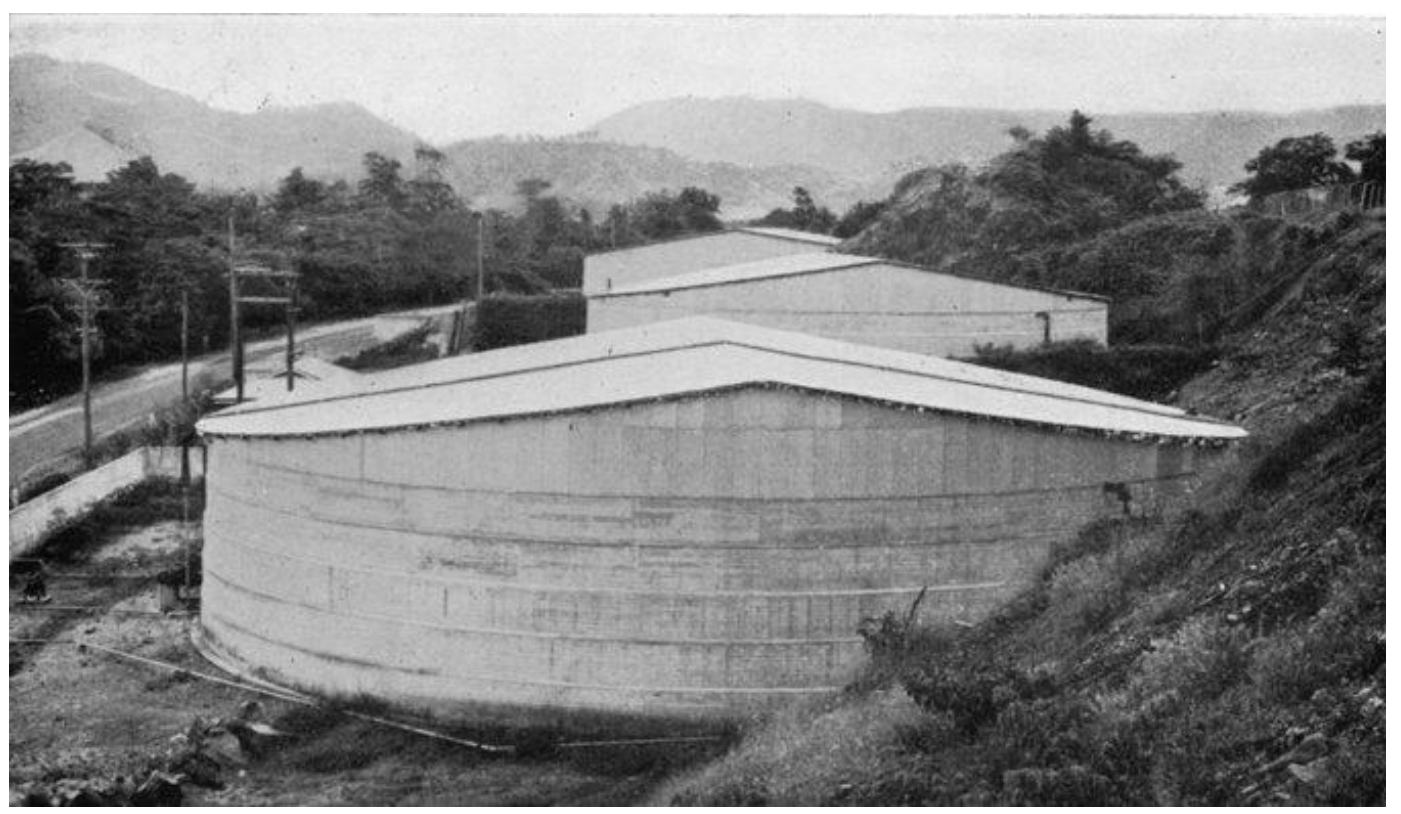

Source: Cairns Regional Council, 2019.

The scale and form were also noted for their aesthetic significance. They had gained aesthetic value as imposingly large industrial ruins in a rainforested urban environment, as tropical forest had overgrown the site by the time of listing (Figure 3) (Department of Heritage and Environment, 2007). The Tanks' aesthetic appeal has developed further through community-initiated activities leveraging on the creativity inspired from the feel of an industrial ruin - adding to the drama of performances and visual arts displays, as well as the ambience created for market days, gala balls and other community activities.

Cultural heritage values arise from both the uses to which an old building has been put and the memories of it in the community. In fact, these values do not necessarily vanish with its new use and they will continue to develop (The Burra Charter, 2013). Many everyday buildings have social values through community attachment to them. These places do not always achieve the threshold required for cultural heritage significance at a regional, state, or national level, and as a result, their significance for the community to which they belong can easily be underestimated (Quantrill, 2011). In essence, social value is usually local. When assessing these places for heritage significance, and in particular their social value, it must involve the community that has used, or will use them, through their reuse (Johnston, 1992). A key point from an interview with an artistic director was that heritage is about people: it is about what happens to people inside of a place, and what happens when people congregate. Correspondingly the Department of Heritage and Environment (2007) assesses social value from the way people interact with a place socially, culturally or spiritually, stating 
eTropic 19.2 (2020) Special Issue: Sustainable Tropical Urbanism

that it exists only if it has been valued by its community over a significant period involving past, present and future generations, and if that value can be expressed tangibly e.g. by being frequently photographed or used in artwork. Social value is embodied in collective memory that shares a group or community's past, and that memory attaches itself to a place, creating symbolic associations to the events that have happened there (Landorf, 2011). However, a place's social value may appear minimal at the time of its reuse, as was the case in the early life of the WWII tanks. In such cases is it likely that the community will later become attached to the place and that it will maintain and develop social value. The case of The Tanks Arts Centre indicates that it will.

Can increasing a place's aesthetic appeal through restoration or reuse strengthen a community's attachment to it therefore assisting in the development of social value? The preservation of heritage does help improve the aesthetic appeal of place and thereby increase community attachment and have a positive impact on community well-being (Power \& Smyth, 2016). Bullen and Love (2011a) describe aesthetic value and landmark quality of a place as providing a visual amenity that strengthens a sense of connection with the place in the community. However, interview discussions proposed that a place can have aesthetic appeal, whether beautiful or ugly, but if there is no human activity in the place how can it have any community attachment? Bies (n.d) reflects this, stating that initially the community was sceptical of 'The Tanks' as it was such an aesthetically imposing structure behind high walls and locked gates. On top of that, it was a series of oil tanks that still had oil in them, and required decontamination.

When 'The Tanks' were first explored for the opportunities offered by the site, Bies, the long-time Community Arts Officer with the Council, said they had to climb up a ladder and let themselves down into the Tanks through an opening in the roof (see Figure 2):

It was like magic going in there, even though it was smelly and gooey, it had some kind of ambience that was completely captivating (Bies, n.d. b).

Similarly, an architect commented:

I will never forget going to the briefing and climbing down into the Tanks, I think it was Tank 5, climbing up the ladder and then down into the space, it hadn't been cleaned properly then. It reminded me of a Sidney Nolan painting, he did these forests, forests of really slender eucalypts, they have a real empirical quality around them. 
They also reminded me of parliament house in Canberra which has got large columns in this big space, it has stuck in my mind as a forest of columns.

The architect noted further that "Architecturally it is of cathedral proportions, the fact that it is obviously an adaption, that gives it the great thing of its heritage value, through its adaption work". Likewise, another architect said, "It is absolutely architecturally magnificent and so versatile, you can do anything you want to do; including the gardens, the whole precinct lends itself to cultural activities and displays".

Figure 2 A first glimpse inside the tanks

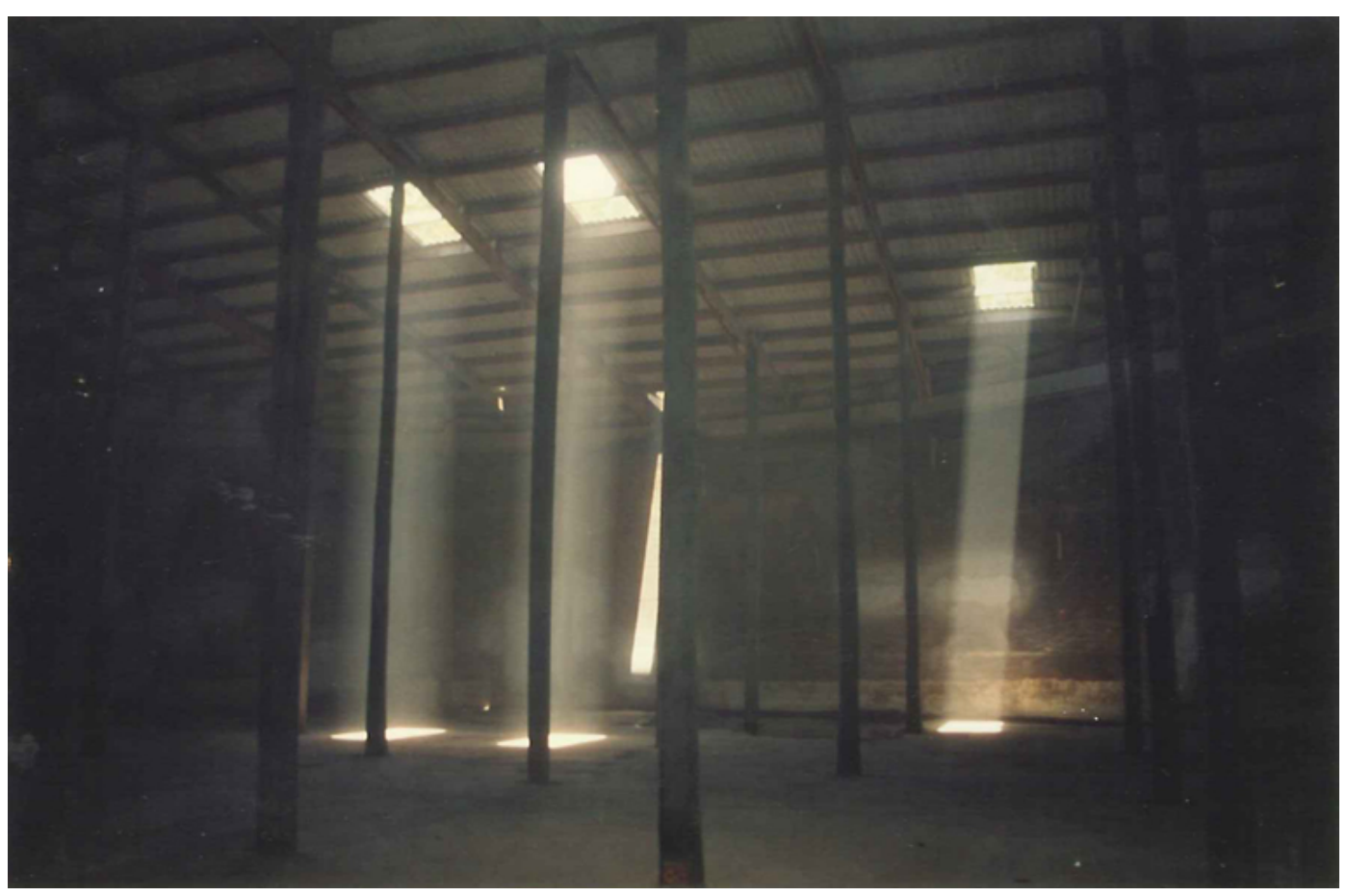

Source: Cairns Regional Council, 2019.

The Tanks Arts Centre offers an aesthetic experience of an industrial ruin; a particular sensory escape within its setting, allowing one to sense the ruin (Edensor (2007). Further, it has developed patina from years of existing in a rainforest - with moss, black mould and lichens clinging to the walls. This patina of age combines with heavily vegetated surrounds to create a tropical 'romantic ruin'. 
Figure 3 The Tanks 2020

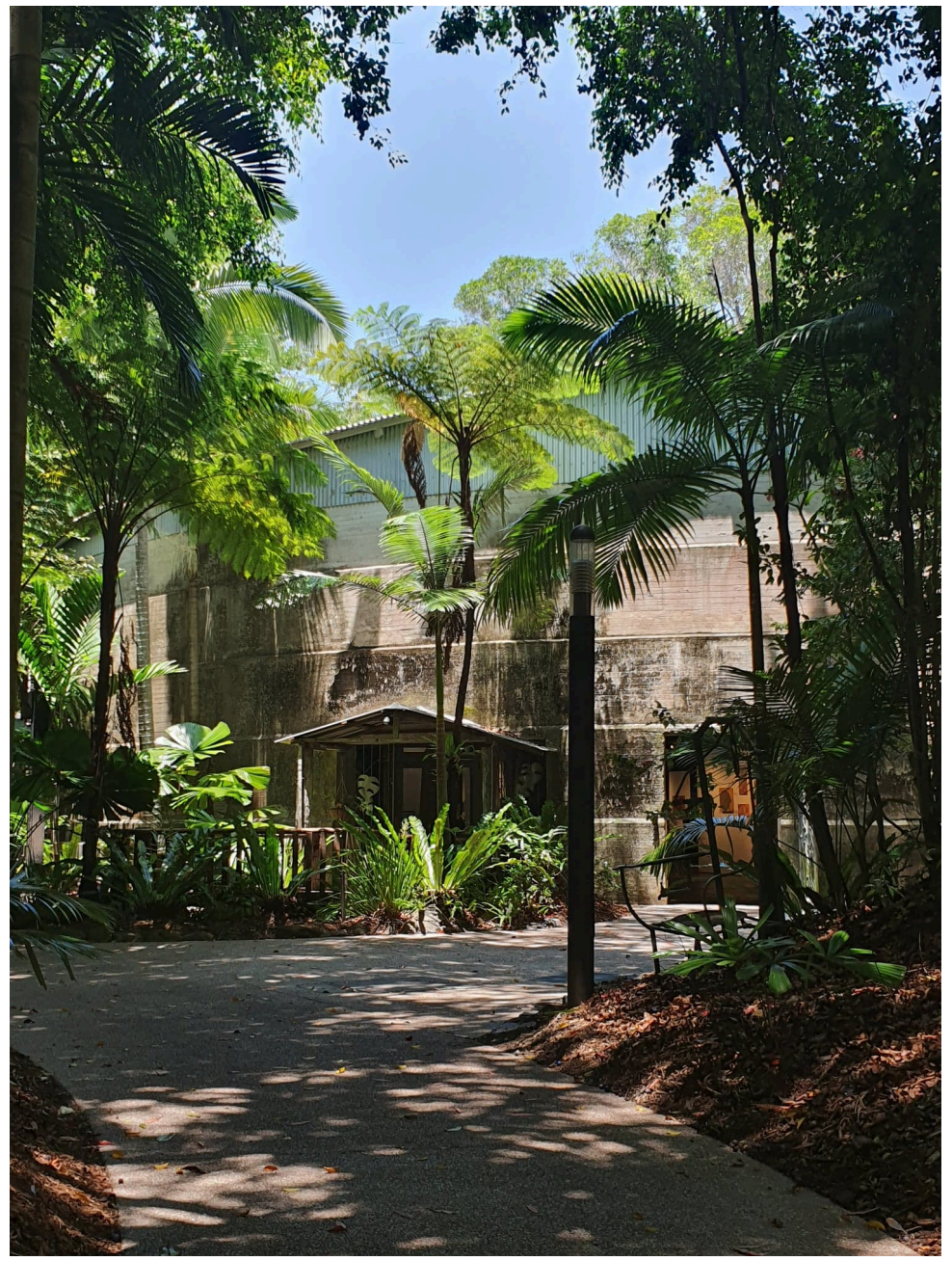

Source: Author's image.

The land The Tanks sits on adjoins the Cairns Flecker Botanic Gardens, itself a place notable for its tropical beauty. McIntyre-Tamwoy (2009) describes the scenic qualities of 'The Tanks' and its position in the Botanic Gardens precinct as a juxtaposition of industrial structures and dense tropical foliage adding to the aesthetic experience, with vines hanging on the gates, giant-leaved climbing plants clinging to the walls, and native fig trees (Ficus benjamina) with their aerial roots claiming the bund walls. Across the road is the lush vegetation of the Centenary Lakes reserve. This type of sensory appeal is described by Chang (2016) in a city context, and likewise demonstrates sensory appeal as an important element in visitor experience, allowing one to be immersed into the aesthetic ambience of the place. Likewise Power and Smyth (2016) describe how certain atmospheres capture a moment of subjectivation in space, the feeling of being a part of the space as a real experience. 
eTropic 19.2 (2020) Special Issue: Sustainable Tropical Urbanism

\section{Community Consultation}

The success of arts and cultural precincts relies on consulting and meeting with the general community and arts stakeholders to ensure the reuse of the heritage place meets the larger region's agenda. As summarised by Lazarus (2014) in a symposium report on creative placemaking, the impetus behind these projects usually came from leaders emerging from within the community who had passion, drive and vision. Councils often encourage feedback from the community in order to develop community infrastructure projects. Cairns City Council actively consulted with the community regarding the reuse of the Tanks Arts Centre in the early 1990s, when they first purchased the tanks, including through an information booth that toured Cairns community shopping malls, community events and libraries - demonstrating that views from a wide demographic were sought (see Figures 4 \& 5).

Figure 4 Photographic display for the Tanks reuse

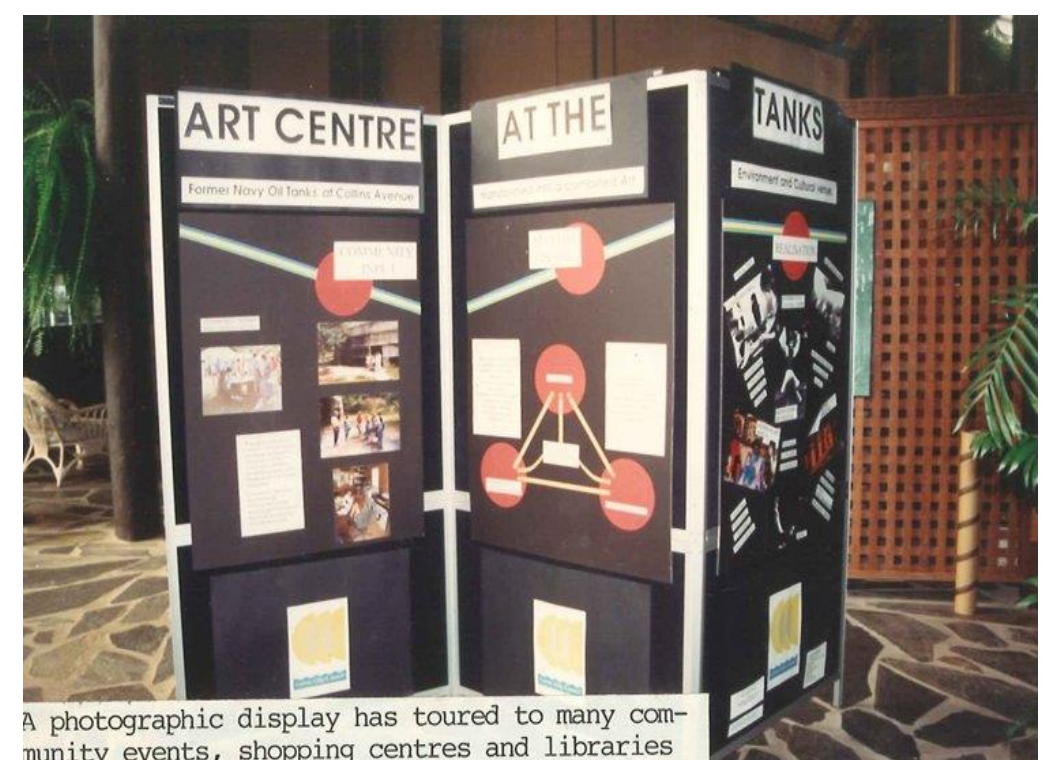

Figure 5 Information booth

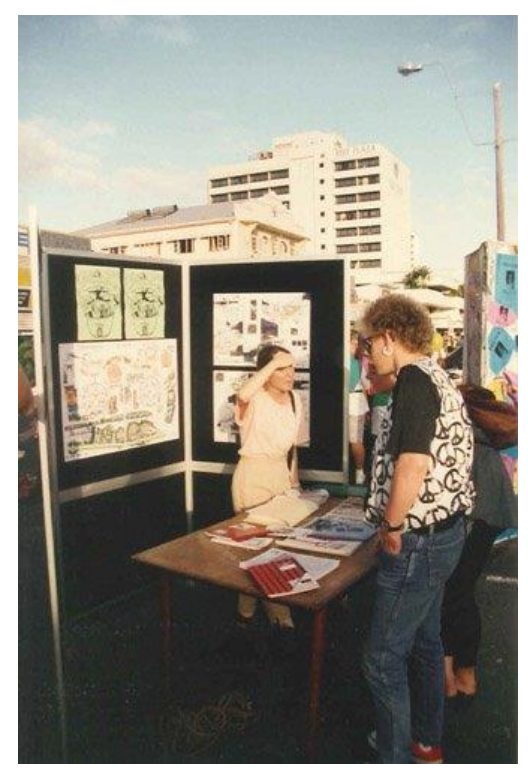

Source: Cairns Regional Council, 2019.

However, stakeholder interviews have given a different insight, proposing that community consultation nowadays usually involves the same group of people that attend everything, and that consultation needs to be broadened and the results listened to. Another perspective was that it is vital to consult the artists and workers who will use the space for it to have maximum benefit. A different person said that community consultation is usually a manipulated story and it would be better to just get things done rather than consult at all. These varying opinions demonstrate some of the challenges experienced with contemporary community consultations, and question whether the right people are consulted in the first place. 
Calls for submissions of plans were made for the adaption of the tanks in the early 1990s. Seven architectural firms responded to the brief. According to the winning architect, the brief included such things such as having a youth centre and community perspective. Some of these concept plans still exist in the Cairns Regional Council archives and demonstrate that different community feedback was considered for the tanks' new use, such as artist studios, cafés and playgrounds.

A sign erected at the main gates, declaring a Cairns City Council Initiative (see Figure 6 ), shows that the Council finally settled on an arts purpose for the building and notified that The Tanks Arts Centre was scheduled to be officially opened in April 1994. The sign reads:

A community centre linking the arts, environment and cultural heritage. The project involves the redesign of three World War II navy storage tanks in collaboration with artists, designers, and the broader community. Funding from the Commonwealth Governments, Local Capital Works Program, and the Australia Council is gratefully acknowledged.

\section{Figure 6 The Tanks Art Centre scheduled opening}

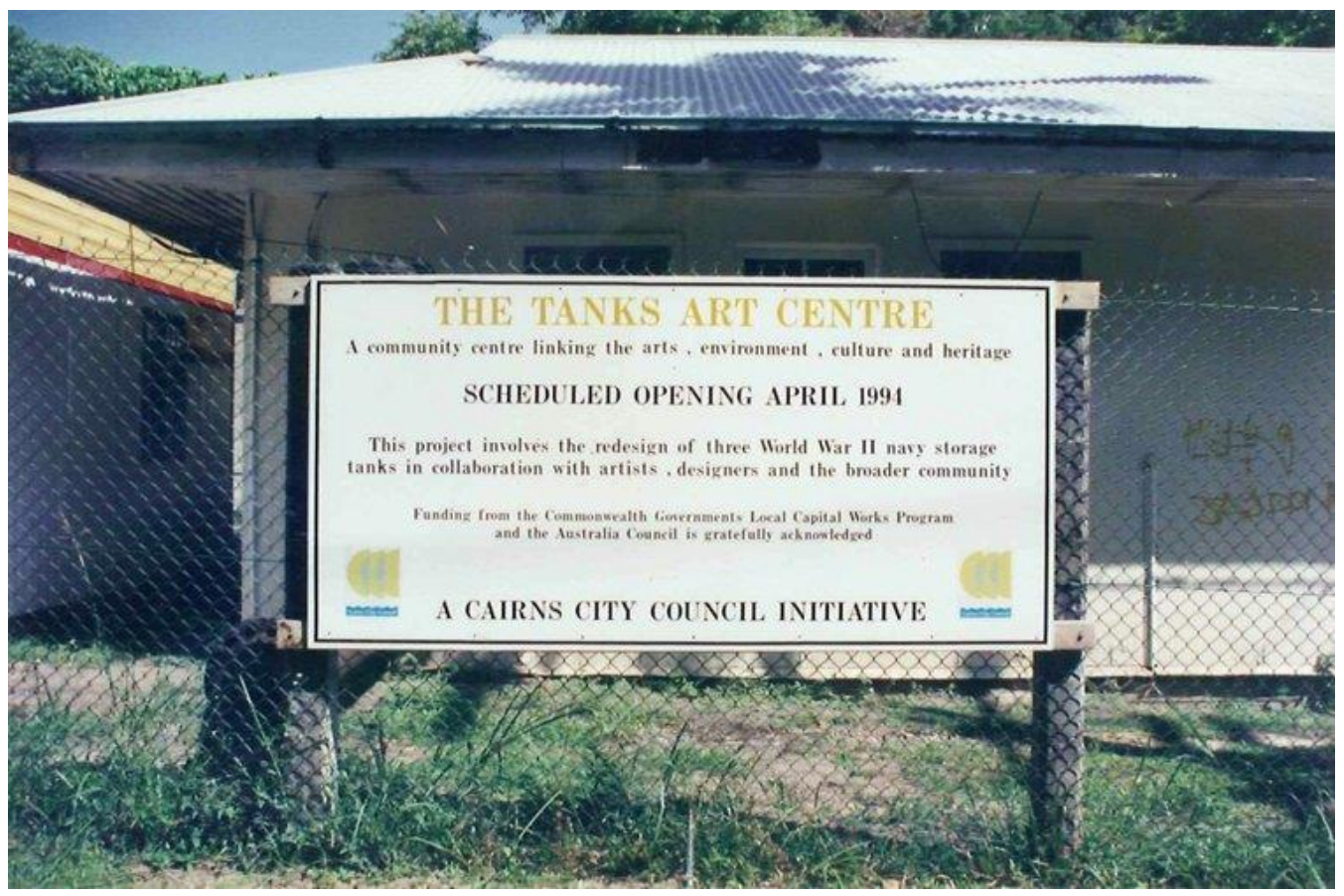

Source: Cairns Regional Council, 2019.

It certainly was a community project and Bies (n.d. c) notes that many in the community volunteered. People from all kinds of backgrounds dropped in and asked how they 
could help, becoming involved in all aspects of the constructions. A Cairns newspaper clipping captured the community spirit, stating that team members from the Flecker Botanic Gardens and Council workers were actively involved in the transformation as well as visual arts students from the local technical college and community volunteers. The place aroused people's curiosity, Bies (n.d. b) explains the appeal: “The Tanks' had a gothic feel about them, and people would come to the doors and be captivated by the space."

Integrating the ideas of the community with those of professionals can develop places that are inspiring and have strong local character. It creates a sense of civic pride for those involved (Barnes et al., 1995). A community environmental art project to create a recreational rainforest and sculptural garden around The Tanks focusing on endangered species was made possible from a $\$ 25,000$ Australia Council grant awarded c.1994. The Cairns Post reported: "Artists have plans for the Tanks" (Brevitt, n.d.). The article explained that artists were to recycle steel found on the site to create gateways and fences and arts installations, while ceramic artists using local clay would create a mural on the entrance wall.

Figure 7 The Tanks ceramic mural wall

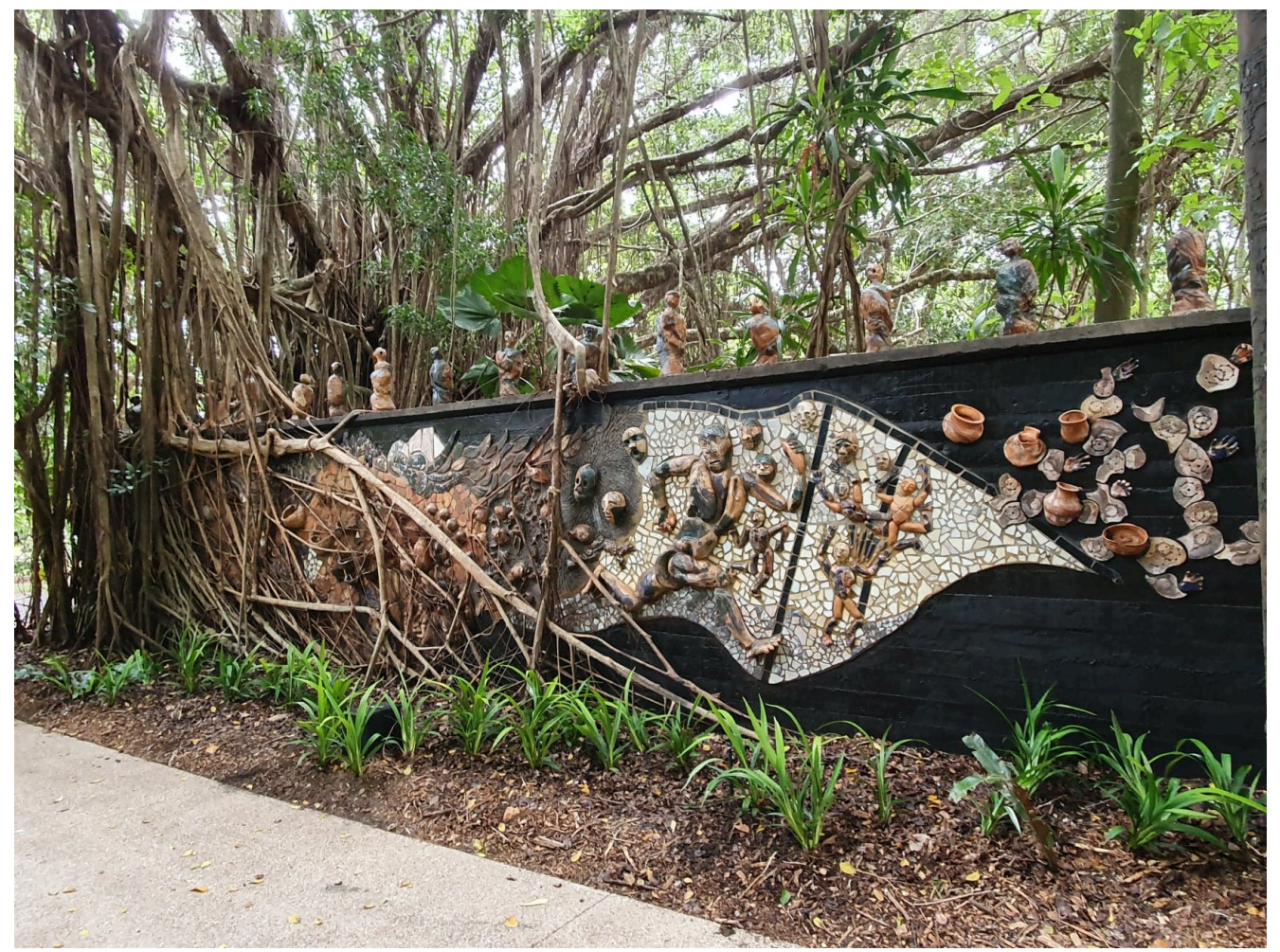

Source: Author's image, 2020.

2 This notion of gothic and the tropics is not mere conjecture; it shows how The Tanks inspire people. Indeed, 'Tropical Gothic' has received substantial academic analysis, see Lundberg et al. (2019) 
eTropic 19.2 (2020) Special Issue: Sustainable Tropical Urbanism

Nicholai Globe, the ceramic artist who led the creation of the mural on the entrance wall, said the work evolved through community workshops with different groups of locals who had gained an interest in the project. The collective of artists agreed upon a story of creation and their place within it. Their ancestors guiding them can be seen in the figures on top of the wall in Figure 7 (Cairns Arts and Culture Map, 2020). The ceramic mural communicates societal values of the time; it demonstrates the skill and craft of those involved, representing this to succeeding generations in relation to public art (Barnes et al., 1995). Volunteers running history tours at The Tanks Arts Centre since 2018 frequently talked about the curiosity that the mural engendered with participants of the tours. Several of the volunteers gathered information about the history and meaning of the piece. This newfound appreciation contributed to a proposal to restore it in 2019. It was delicately cleaned to bring the colour out and refix any loose pieces. A weeping fig tree (Ficus benjamina), slowly taking over the mural and the bund wall that it is situated on, was carefully pruned to preserve and respect both fig tree and mural. The restorers said that as they worked passers-by would stop and enquire, or relate stories about the artwork. When the Tanks was assessed in 2007 for nomination to the Queensland Heritage Register, it was noted that key elements of the WWII site had been reused to create the sculpture garden in 1994 and had since developed their own aesthetic and acquired social value for the community (Department of Heritage and Environment, 2007). A similar example is described by Gray et al. (2017), where a creative regeneration approach was instrumental in the redevelopment of Fyansford Paper Mills in Geelong. A community artisans' approach was key to the project's success in developing new aesthetic value, community attachment and social meaning to the place.

Art is about exploring the human condition in relation to our built environments; the Tanks Arts Centre is in a unique position to be able to do this. The place itself inspires thinking about the past and present, decay and regeneration, who we are and who we were. A recorded interview with Trimarchi, the manager of the facility between 2005 and 2009, reveals that he was interested in the potential of the iconic facility in terms of what it was able to deliver in its intimate setting. He identified the need to broaden the audience from a visual art focus to include more of the Cairns community which he implemented through a focus on programming live music as well as visual arts as the nature of the facility was conducive to both these art forms (Trimarchi, n.d.).

A place must have multiple uses for the community, including structured events, community events, and free general use, in order for it to grow community attachment; this idea was repeated several times in 2019 interviews about the Tanks. It's about programming the place to build community attachment and community engagement, said an artistic director. Having the support of the Regional Council and government arts and cultural funding, gives stable and long-term access for the community 
eTropic 19.2 (2020) Special Issue: Sustainable Tropical Urbanism

rehearsal and performance space. Examples of the groups that have utilised The Tanks are: Graft'n'Arts, one of the first community youth arts groups that took residence in the Tanks in the late 1990s (Cairns Regional Council, 2004); Cairns Tropical Pride Festival, since 2004 (Byford, 2017); Cairns Arts Society's annual community exhibitions and arts workshops, now in their fourteenth year (Cairns Art Society, 2020); community theatre group Tropical Arts Association, since 2008 (Tropical Arts, 2020); and many multicultural community days and programs supporting the arts community (Tanks Arts Centre, 2020). These community-initiated groups have been the incubators in the development of community driven exhibitions and events that get people together, helping to build their social networks along with their attachment to the place.

The extent of community attachment to the site was evident when celebrations of 20 years of the Tanks as an arts centre, and 70 years since the tanks were built as a WWII infrastructure, were held in 2014. These celebrations involved many people from the community through their ideas, stories, and photographic memories, enhancing the official histories of the Tanks Arts Centre's WWII heritage and its new use as a community arts and cultural space. Top-line entertainment was programmed with sellout performances, and a visual art display retraced the memories of the tanks. A grand birthday celebration was held, bringing the Cairns military and community groups together, reigniting Cairns community memories and strengthening further attachment to the place.

During these celebrations a survey was conducted by James Cook University Bachelor of Education students to ascertain the level of community feeling and attachment to the Tanks Arts Centre (Kerr \& Davies, 2014). The survey responses revealed the Cairns communities' attachment to the Tanks was significant. Recorded responses claimed: "The Tanks is the only good venue in town attracting top musicians"; "great venue with a point of difference"; "extremely iconic venue to Cairns". A survey question asking the role the Tanks played in promoting a sense of community prompted these responses: "Sense of community in Cairns is experiencing system degradation on all levels, community based organisations such as Tanks are invaluable and have become a very significant thread in local social fabric", and "The Tanks are a part of Cairns history; they are very relevant and important in creating a sense of community". Those who believed the absence of the Tanks would have a significant impact on them commented: "The Cairns community would lose part of its soul" and "Impact would be great". Tanks brings together members from all sectors of the community. It is an essential hub. Many respondents see The Tanks Arts Centre as a community gathering space and the monthly markets are integral to Cairns community life. A common sentiment was that they would be devastated if the Tanks Arts Centre no longer existed. The results illustrate Bullen's (2011) notion that heritage 
eTropic 19.2 (2020) Special Issue: Sustainable Tropical Urbanism

buildings are cultural icons within the community and their preservation impacts community well-being, attachment to place and social sustainability.

\section{Conclusion}

There are many ways of developing strong arts and cultural places; there is not a common blueprint that works everywhere. Each place has its own identity through its community, as it is the users that add sense of place, personality and purpose that go to make up social value (Lazarus (2014). Similarly, Ed Blakley, Honorary Professor of Urban Policy at the United States Studies Centre, University of Sydney, says that a public space's success requires three ingredients: a space that interacts with people; a space that offers interest; and a space that integrates well within its community (Hoyne, 2016.) Further, Beardsley's theory of aesthetics suggests that a place must offer complexity, intensity and unity (Goldman, 2005). The Tanks Arts Centre offers all these ingredients without them being imposed artificially. Its adaption as an arts and cultural space offers continuous interaction with people; it provides an intriguing past as part of an event of great significance, WWII; and its stone-like walls and vegetation fit well into the parks and cliffs surrounding it, providing a tropical aesthetic appreciated by locals and tourists alike. The three concrete tanks, pumphouse, and original bund and perimeter wall make up the Tanks Arts Centre site, and today these WWII relics have become a centrepiece of Cairns community and cultural life. The heritage value of the WWII facility has been conserved through its heritage listing and careful conservation planning. Through its adaptive reuse, social value has been built through programming and community-initiated activities, while the aesthetics of the place continue to grow from its curious nature and tropical rainforest setting.

Industrial heritage, although its aesthetic value can be subjective and rarely inspires keen social heritage value, can be adapted well to an arts or cultural space because of the large spaces and unusual architecture. Once adaptively reused, these arts spaces will acquire increasing social value because of the positive experiences of many in the community attending events there, and the adaptation process will probably also increase the aesthetic appeal of a place, thereby further increasing its social value because the community prefers places that are attractive or interesting. The successful reuse of the Tanks Arts Centre, as well as the Fyansford Paper Mill in Geelong, Carriageworks in Sydney, and those referred to in Chen et al., including No. 46 Fangjia Huttong a former Machine tool plant in Beijing, M50 former textiles factory, and the Chongqing Huangjeuping Art Zone a former tank warehouse in Shanghai, all have the common thread of beginning from a grassroots base (Chen et al., 2016). The present findings demonstrate that social and aesthetic values continue to grow through community-initiated approaches to the reuse of space for arts and culture, resulting in a snowballing of community attachment to the place. While community-led initiatives 
eTropic 19.2 (2020) Special Issue: Sustainable Tropical Urbanism

have the advantage of drive and passion from within the community, they can result in failure if one or more of the passionate drivers leaves, or if the direction of the leaders becomes misguided. It is noted that ongoing success in most cases is also reliant on government funding and administration which gives structure, consistency and stability, and differs from community-led administration. This paper has explored a specific case study set in a unique location in tropical north Australia. It notes that further research is required regarding how to better validate social and aesthetic values, existing and evolving, that can demonstrate a groundswell of support for historically significant industrial places to be reused for common community purposes. 
eTropic 19.2 (2020) Special Issue: Sustainable Tropical Urbanism

\section{References}

Australian Government. (2006). Conservation of Australias Historic Places (37). https://www.pc.gov.au/inquiries/completed/heritage

Bailey, J. (2009). Meaningful Measurement. A review of the literature about measuring artistic vibrancy.https://www.australiacouncil.gov.au/workspace/uploads/files/research/literature revi ew - artistic v-54e17ad081a2a.pdf

Barnes, L., Winikoff, T., Murphy, C., \& Nicholson, A. M. (1995). Places not spaces: placemaking in Australia. Envirobook.

Bianchi, M. (2014). The Magic of Storytelling: How Curiosity and Aesthetic Preferences Work (Vol. 8). https://doi.org/10.5018/economics-ejournal.ja.2014-44

Bies, C. (n.d). Cairns Regional Council Archive recording 3 (3)[Archival Recording ]. Cairns Regional Council.

Bies, C. (n.d. a). Cairns Regional Council Archive recording 4 [Interview].

Bies, C. (n.d. b). Cairns Regional Council Archive recording 4 (4)[Arhive recording]. Cairns Regional Council.

Bies, C. (n.d. c). Cairns Regional Council archive recording 5 (5)[Archive recording]. Cairns Regional Council.

Bottoms, T. (2015). Cairns: city of the South Pacific: a history 1770-1995. Bunu Bunu Press.

Brevitt, A. (n.d.). Artists have plans for the tanks. Cairns Post.

Bullen, P., \& Love, P. (2011a). Adaptive reuse of heritage buildings. Structural Survey, 29(5), 411 421. https://doi.org/10.1108/02630801111182439

Bullen, P., \& Love, P. (2011b). Factors influencing the adaptive re-use of buildings. Journal of Engineering, Design and Technology, 9(1), 32-46. https://doi.org/10.1108/17260531111121459

Bullen, P. A. (2007). Adaptive reuse and sustainability of commercial buildings. Facilities, 25(1/2), 20-31. https://doi.org/10.1108/02632770710716911

Byford, I. (2017). Passing glances : a history of gay Cairns. https://www.facebook.com/ALGArchives/posts/new-book-passing-glances-a-history-of-gaycairnsfrom-the-establishment-of-cairns/434118206928827/

Cairns Art Society. (2020). Cairns Art Society. Retrieved from https://www.cairnsartsociety.com/about

Cairns Arts and Culture Map. (2020). Ceramic Mural Wall. Cairns Regional Council. Retrieved from https://www.cairnsartsandculturemap.com.au/ceramic-mural-wall

Cairns City Council. (2010). Tanks Tales.

Cairns Regional Council. (2004). Making a Bollywood Film with budding young stars

Cantell, S. F. (2005). The adaptive reuse of historic industrial buildings: regulation barriers, best practices and case studies Virginia Polytechnic Institute and State University.

Chang, T. (2016). 'New uses need old buildings': Gentrification aesthetics and the arts in Singapore. Urban Studies, 53(3), 524-539. https://doi.org/10.1177/0042098014527482

Chaudhury, S., \& Lundberg, A. (2018). Singapore as a creative city: Vignettes from the perspective of la flâneuse tropique. eTropic: electronic journal of studies in the tropics, 17(2), 110-131. https://doi.org/10.25120/etropic.17.2.2018.3660

Chen, C. S., Chiu, Y. H., \& Tsai, L. C. (2018). Evaluating the adaptive reuse of historic buildings through multicriteria decision-making. Habitat International, 81, 12-23. https://doi.org/10.1016/j.habitatint.2018.09.003

Chen, J., Judd, B., \& Hawken, S. (2016). Adaptive reuse of industrial heritage for cultural purposes in Beijing, Shanghai and Chongqing. Structural Survey, 34(4/5), 331-350.

https://doi.org/10.1108/SS-11-2015-0052 
Conejos, S., Langston, C., Chan, E. H. W., \& Chew, M. Y. L. (2016). Governance of heritage buildings: Australian regulatory barriers to adaptive reuse. Building Research and Information, 44(5-6), 507-519. https://doi.org/10.1080/09613218.2016.1156951

Cossins, N. (2016). Values and Meanings. In J. Douet (Ed.), Industrial Heritage Re-Tooled: The TICCIH Guide to Industrial Heritage Conservation. Routledge. http://ebookcentral.proquest.com/lib/jcu/detail.action?doclD=1977967

Department of Environment and Heritage. (2004). Adaptive Reuse: Preserving our past, building our future. Commonwealth of Australia.

http://www.environment.gov.au/heritage/publications/adaptive-reuse

Department of Heritage and Environment. (2007). Queensland Heritage Register. https://environment.ehp.qld.gov.au/heritage-register/detail/?id=602605

Dyson, K., Matthews, J., \& Love, P. E. D. (2016). Critical success factors of adapting heritage buildings: an exploratory study. Built Environment Project and Asset Management, 6(1), 4457. https://doi.org/10.1108/bepam-01-2015-0002

Eccles, J. (2008). Adaptive Reuse Goes West: Casula Powerhouse and Carriageworks, Sydney. Art Monthly Australia(209), 12-15. https://search.informit.com.au/documentSummary;dn=186032566655889;res=|ELLCC

Edensor, T. (2007). Sensing the Ruin. The Senses and Society: The Senses and the City, 2(2), 217-232. https://doi.org/10.2752/174589307X203100

Goldman, A. (2005). Beardsley's legacy: The theory of aesthetic value. The Journal of aesthetics and art criticism, 63(2), 185-189. https://doi.org/10.1111/j.0021-8529.2005.00196.x

Gray, F., Freeman, C. G., \& Novacevski, M. (2017). Milling it over: Geelong's new life in forgotten places. Historic Environment, 29(2), 58-69. https://australia.icomos.org/wpcontent/uploads/Milling-it-over-Geelong\%E2\%80\%99s-new-life-in-forgotten-places-vol-29$\underline{\text { no-2.pdf }}$

Hashemnezhad, H., Heidari, A., \& Mohammad Hoseini, P. (2013). Sense of Place" and "Place Attachment. International Journal of Architecture and Urban Development, 3(1), 5-12. http://ijaud.srbiau.ac.ir/article 581 a90b5ac919ddc57e6743d8ce32d19741.pdf

Hoyne, A. (2016). The Place Economy. Andrew Hoyne Design Pty Ltd. https://hoyne.com.au/theplace-economy/volume-1/

Ireland, T. (2002). Giving value to the Australian historic past: Historical archaeology, heritage and nationalism. Australasian Historical Archaeology, 20(2002), 15.

Johnston, C. (1992). What is social value?: a discussion paper (0947175148;9780947175146;). https://www.academia.edu/1098089/What is Social Value A Discussion Paper

Johnston, C. (2016). Seeing through others|' eyes: Understanding the aesthetics and meanings of place. Historic environment, 28(1).

Kerr, C. A., \& Davies, H. (2014). Tanks Arts Centre Community Survey [Undergraduate research project]. James Cook University.

Landorf, C. (2011). Measuring social value of heritage: A framework based on the evaluation of sustainable development SAHANZ Annual Conference, Brisbane, Australia.

Lazarus, F. (2014, 30 - 31 May 2014). Building Trust and Relationship The Role Of Artists \& The Arts In Creative Placemaking, Baltimore. http://www.goethe.de/ins/us/was/pro/creative placemaking/2014 Symposium Report.pdf

Lundberg, A., Ancuta, K., \& Stasiewicz-Bienkowska, A. (2019). Tropical Gothic: arts, humanities and social sciences. eTropic: electronic journal of studies in the tropics, 18(1), 1-11. https://doi.org/10.25120/etropic. 18.1.2019.3685

MacCallum, D., Babb, C., Curtis, C., \& ProQuest. (2019). Doing research in urban and regional planning: lessons in practical methods. Routledge. https://www-taylorfranciscom.elibrary.jcu.edu.au/books/9781315818894

McIntyre-Tamwoy, S. (2009). The Flecker Botanic Gardens, Tanks Arts Centre and Centenary Lakes: conservation management plan. https://researchonline.jcu.edu.au/8142/ 
Mehr, S. Y., \& Wilkinson, S. (2018). Technical issues and energy efficient adaptive reuse of heritage listed city halls in Queensland Australia. International Journal of Building Pathology and Adaptation, 36(5), 529-542. https://doi.org/10.1108/ijbpa-02-2018-0020

O'Connor, J., \& Gu, X. (2014). Creative industry clusters in Shanghai: a success story? International Journal of Cultural Policy, 20(1), 1-20.

Power, A., \& Smyth, K. (2016). Heritage, health and place: The legacies of local community-based heritage conservation on social wellbeing. Health and Place, 39, 160-167. https://doi.org/10.1016/j.healthplace.2016.04.005

Quantrill, T. (2011). Whose heritage?: a regional perspective on the paradoxical devaluation of social value in cultural heritage James Cook University. School of, Arts \& Social Sciences]. Townsville, Qld Dissertation.

Spaces, C. (2016). The Substation | Case Studies | Creative Spaces. http://www.creativespaces.net.au/case-studies/the-substation

Tanks Arts Centre. (2020). Community Events. Retrieved 25/02 from https://www.tanksartscentre.com/whats-on/community

The Australian War Memorial. (2018). Second World War, 1939-1942. Australian War Memorial. Retrieved 01/08/2018 from https://www.awm.gov.au/articles/second-world-war

The Burra Charter. (2013). The Australian ICOMOS Charter for Places of Cultural Significance (Article 21). https://australia.icomos.org/wp-content/uploads/The-Burra-Charter-2013Adopted-31.10.2013.pdf

Throsby, D. (2007). The Value of Heritage Heritage Economics Workshop, Australian National University.

Trimarchi, N. (n.d.). Cairns Regional Council archive recording 7 (7)[Archival Recording ]. Cairns Regional Council.

Tropical Arts. (2020). Where we came from. Retrieved 25/05 from http://tropicalarts.org/where-wecame-from/

Watson, M. (2016). Adaptive Reuse and Embodied Energy. In J. Douet (Ed.), Industrial Heritage Re-Tooled: The TICCIH Guide to Industrial Heritage Conservation (pp. 136-141). Routledge. https://ebookcentral.proquest.com/lib/jcu/reader.action?doclD=1977967\&ppg=194

Westbury, M. (2016). Making small things easy. In A. Hoyne (Ed.), The Place Economy (Vol. 1, pp. 324-332). Hoyne.

Yung, E., \& Chan, E. (2015). Evaluation of the social values and willingness to pay for conserving built heritage in Hong Kong. Facilities, 33(1/2), 76-98. https://doi.org/doi:10.1108/F-02-20130017

Yung, E., Chan, E., \& Xu, Y. (2014). Community-Initiated Adaptive Reuse of Historic Buildings and Sustainable Development in the Inner City of Shanghai. Journal of Urban Planning and Development, 140(3), 05014003. https://doi.org/10.1061/(asce)up.1943-5444.0000174 


\section{Acknowledgements}

The completion of this paper would not have been possible without the participation and assistance of many people who gave their insights in anonymous interviews. I would also like to acknowledge my academic supervisors, Associate Professor Lisa Law, Professor Ryan Daniel and Dr Janice Wegner for their guidance in completing the paper.

Anthony Castles is a PhD candidate in society and culture at James Cook University. His research interests are in abandoned places, architecture, aesthetics, community, arts and culture. Anthony's current research examines how places no longer useful for their original purpose can conserve and build new social and aesthetic values through reuse for arts and culture. 